\title{
Telaah Profil Karakter Kinerja Sebagai Upaya Pengembangan Kesuksesan Karir Mahasiswa
}

\author{
Ismira*1, Ahman', Mamat Supriatna ${ }^{3}$, Jendriadi ${ }^{4}$ \\ 1,4STKIP Adzkia Padang, Indonesia, \\ *Correspondence Adress, Email : ismira70@yahoo.co.id. \\ 2,3Universitas Pendidikan Indonesia, Bandung, Indonesia \\ ${ }^{2}$ Email: ahman@upi.edu. ${ }^{3}$ Email: ma2t.supri@gmail.com \\ ${ }^{4}$ Email: rumbenasli@yahoo.co.id.
}

DOI: $\underline{\text { https://doi.org/10.15548/turast.v7i1.344 }}$

(Diterima: 15 Januari 2019. Disetujui: 24 Juni 2019. Diterbitkan: 30 Juni 2019)

\begin{abstract}
Abstrct
This paper discusses the character of performance including self-identity, ways of thinking, attitudes and skills aspects in developing student's careers. A descriptive quantitative approach is used performance character instruments that measure three aspects, namely knowledge, attitudes and skills aspects. The results showed that the character quality of student performance was in the quality category with an average of $61.17 \%$. Knowledge aspect is $61.4 \%$ with quality criteria, attitude aspect is $74.4 \%$ with quality criteria and skill aspect is $47.72 \%$ with sufficient quality. It is concluded that the attitude aspect has a major role as an effort to develop student career. It implies that new model is needed to develop students' character..
\end{abstract}

Keywords: Character, performance, career

\section{PENDAHULUAN}

Karakter kinerja (Performance Character) digambarkan dalam bentuk kepribadian yang mewakili nilai-nilai kualitas kerja yang dimiliki individu dalam rangka meraih kesuksesan kerja dan kesuksesan hidup (Meithiana, 2017; Putra \& Suharnomo, 2012). Karakter kinerja meliputi fokus (focus), percaya diri (confidence), Kompetisi (competitiveness), disiplin diri (self
Discipline), dan kekuatan mental (mental toughness) (Ubaedy, 2013). Karakter Kinerja dapat didefinisikan sebagai pilihan yang baik dan sikap positif didasari oleh pengetahuan, sikap dan keterampilan yang dimiliki individu dalam melaksanakan pekerjaan, sehingga memberi pengaruh kepada kualitas hasil pekerjaan dan memberi dampak kepada kesuksesan pribadi dan kesuksesan sosial (Kartika 
\& Kaihatu, 2010). Pengertian ini menjelaskan bahwa karakter kinerja akan sangat dipengaruhi oleh kualitas pengetahuan, sikap dan keterampilan yang dimiliki individu.

Karakter Kinerja (Performance Character) memiliki makna yang hampir bersamaan dengan karakter mandiri, kecakapan pribadi, kecakapan hidup, produktivitas kerja dan kepribadian yang efektif serta beberapa istilah lainnya (Astuti, 2017; Mahadin Shaleh \& Firman, 2018). Kesemua istilah ini mengarah kepada pola perilaku atau kepribadian individu dalam membangun kemapanan pribadi, kemapanan dalam dunia kerja, kehidupan sosial yang mengarah kepada kemandirian karir atau kesuksesan karir.

Karakter Kinerja adalah sesuatu yang tumbuh dan berkembang sepanjang kehidupan individu sejak lahir sampai usia tua. Karakter kinerja berkembang melalui proses pendidikan yang diperoleh oleh individu dari keluarga, sekolah dan lingkungan. Kebiasaan orang tua mendidik anak untuk hadir tepat waktu di sekolah akan menumbuhkan karakter disiplin dalam diri anak. Kebiasaan berbagi yang ditumbuhkan oleh guru disekolah terhadap siswa, akan menumbuhkan sikap sosial yang baik pada siswa. Pembiasaan bersyukur untuk setiap rizki yang diperoleh akan menumbuhkan karakter religius dalam diri individu (Husin, 2018; Yudistira, 2014). Karakter atau karakter kinerja akan terus berkembang semakin baik apabila kebiasaan itu dipelihara di sepanjang rentang kehidupan individu (Astawa, 2016; Bartin, 2018;
Muhammad, Dasar, Oleh, \& Supriano, 2017).

Lembaga pendidikan memiliki peran yang sangat signifikan dalam mengembangkan karakter kinerja sejak dari usia pra sekolah sampai perguruan tinggi (Haryani, Wadin, \& Sofino, 2014; Tenriawaru, 2014). Peran dominan pengembangan karakter kinerja di dunia pendidikan berada pada layanan bimbingan dan konseling serta lebih spesifik dilaksanakan dalam bidang bimbingan karir (Indana, 2017). Layanan bimbingan karir dalam menjalankan programnya berpedoman kepada tugas perkembangan peserta didik yang disesuaikan dengan tingkat usia (Anggraini, 2017; Atikah, 2016).

Penelitian ini mengungkap profil karakter kinerja mahasiswa etnik Minangkabau dalam layanan bimbingan karir di perguruan tinggi. Tujuan penelitian ini untuk membantu mahasiswa dalam perencanaan karir termasuk meraih kesuksesan karir. Mahasiswa dalam teori perkembangan karir yang dikemukakan oleh Donald Super, berada dalam tahap eksplorasi (eksploration) dan pada sub tahap transisidengan rentang usia18-21 tahun.Tahapan ini ditandai dengan menonjolnya pertimbangan yang lebih realistis untuk memasuki dunia kerja atau latihan profesionalisme serta berusaha mengimplementasikan konsep diri (Suherman, 2009). Dimensi kematangan karir mahasiswa menurut Super, mencakup matangnya perencanaan karir (Career Planning), kemampuan mengeksplorasi karir (career eksploration), keberanian pengambilan keputusan karir (career 
decition making) dan informasi mengenai dunia kerja (world of work information).

Penelitian (Faqeer-Ul-Ummi, Javed, \& Amjad, 2014) tentang karakter kinerja dengan pendekatan lingkungan. Mereka menemukan bahwa "In present study, personality and career success results influenced by other research factors "person environment fit andjob performance". These factors had continuous effect on career success (kepribadian dan kesuksesan karir dipengaruhi oleh faktor kesesuaian lingkungan organisasi dan kinerja. Faktor-faktor ini memiliki efek berkelanjutan pada kesuksesan karir). (Ballout, 2007) meneliti kesuksesan karir dengan pendekatan pendidikan dan pengalaman. Dia menemukan bahwa "Human capital factors, including education level, work investment, workexperience, and the number of hours worked are each positively related tocareer success(Faktor Manusia termasuk tingkat pendidikan, investasi, pengalaman kerja dan jumlah jam kerja, masing-masing berpengaruh positif terhadap kesuksesan karir). Menarik karena Ballout juga menemukan bahwa kesesuaian budaya berpengaruh positif terhadap kesuksesan karir.

Penelitian pendahuluan tentang karakter kinerja mahasiswa, ternyata menunjukkan hasil yang belum signifikan sebagai syarat tercapainya kesuksesan karir. Penelitian pendahuluan yang dilakukan terhadap 40 mahasiswa etnik Minangkabau pada sebuah perguruan tinggi swasta tergambar dalam tabel 1.

Tabel 1

Data Hasil Studi Pendahuluan Karakter Kinerja Mahasiswa

\begin{tabular}{lclc}
\hline Aspek & No. & Indikator & $\begin{array}{c}\text { Rata- } \\
\text { Rata } \\
\mathbf{( \% )}\end{array}$ \\
\hline Penge- & 1 & Rasa Ingin Tahu & 65,52 \\
tahuan & 2 & Cinta Belajar & 63,85 \\
$62,3 \%$ & 3 & Berpikir Kritis & 59,38 \\
& 4 & Berpikir Kreatif & 60,44 \\
Sikap & 5 & Percaya Diri & 62,86 \\
$60,3 \%$ & 6 & Gigih & 60,65 \\
& 7 & Integritas & 61,58 \\
& 8 & Komitmen & 60,47 \\
& 9 & Tanggungjawab & 62,38 \\
& 10 & Sosial & 58,48 \\
& 11 & Proaktif & 55,64 \\
Kete- & 12 & Bekerja Cepat & 54,82 \\
ram- & 13 & Kerjasama & 53,65 \\
pilan & 14 & Komunikasi & 52,89 \\
52,7 & 15 & Negosiasi & 51,42 \\
& 16 & Manajemen & \\
& & Konflik & 50,71 \\
\hline Rata-rata & \multicolumn{3}{c}{58,4} \\
\hline
\end{tabular}

Studi pendahuluan menunjukkan rata-rata karakter kinerja mahasiswa sebesar $58,4 \%$ pada kriteria cukup berkualitas. Semua aspek karakter kinerja meliputi aspek pengetahuan $(62,3 \%)$, aspek sikap $(60,3 \%)$ dan aspek keterampilan $(52,7 \%)$ berada pada kriteria cukup berkualitas. Kualitas karakter kinerja sebagaimana hasil penelitian pendahuluan tersebut di atas belum memadai sebagai syarat mencapai kesuksesan karir. Aspek keterampilan bahkan mendekati kepada kriteria kurang berkualitas. Kondisi karakter kinerja mahasiswa ini menjadi bahan evaluasi untuk menyusun berbagai program dan 
strategi untuk mengembangan karakter kinerja di perguruan tinggi. Hasil studi pendahuluan tentang karakter kinerja mahasiswa berdasarkan aspek karakter kinerja meliputi aspek pengetahuan, sikap dan keterampilan juga terlihat pada grafik 1 berikut ini :

Karakter Kinerja Mahasiswa
STKIP Adzkia
Tahun 2016
Rata-rata : 58,3\% (cukup baik)
Pengetahuan @ Sikap
Keterampilan

\section{Grafik 1 \\ Data Pendahuluan Karakter Kinerja Mahasiswa}

Evaluasi menyeluruh terhadap tingkat kemandirian pelajar terutama mahasiswa diperguruan tinggi juga menunjukkan gejala yang memprihatinkan. Hasil penelitian (Kartadinata, 1988) menemukan tiga gejala yang meresahkan tentang persoalan kemandirian manusia Indonesia, yaitu : 1) ketergantungan disiplin kepada kontrol luar bukan karena niat sendiri yang ikhlas, 2) sikap tidak peduli terhadap lingkungan hidup 3) sikap hidup konformistik tanpa pemahaman dan kompromistik dengan mengorbankan prinsip.

Penelitian lain menunjukkan bahwa jumlah subjek yang mandiri secara finansial dan sepenuhnya lepas dari keluarga hanyalah $50 \%$ dari total responden yang diteliti. Fenomena di atas diperkuat dengan data Badan Pusat Statistik (BPS) Indonesia yang mencatat adanya 7,4 juta pengangguran terbuka tercatat pada Februari 2015. Pengangguran tersebut dipenuhi oleh sarjana yang menganggur (BPS, 2015).

Faktor yang menyebabkan tingginya tingkat pengangguran di kalangan sarjana (antara lain : Pertama, Paradigma sarjana. Sebagian besar sarjana hanyalah berkeinginan menjadi pencari kerja (job-seeker) dan jarang yang berkeinginan menjadi pencipta kerja (job-creator). Biasanya disebabkan karena lulusan yang menginginkan kemudahan dan menghindari resiko kegagalan; Kedua, Kurangnya lapangan pekerjaan yang disebabkan lemahnya kinerja sektor riil dan daya saing Indonesia; Ketiga, Ketidaksesuaian keahlian lulusan dengan kriteria yang dibutuhkan oleh perusahaan tempat kerja; Keempat, Kompetensi lulusan karena faktor sempitnya jumlah lapangan pekerjaan di Indonesia. Sistem pendidikan di Indonesia yang terlalu berorientasi ke bidang akademik, sehingga para sarjana lemah dalam soft skill.

Beberapa hasil penelitian termasuk data BPS menunjukkan gejala yang memprihatinkan tentang karakter kinerja mahasiswa. Secara teoretik, karakter kinerja dan implementasinya sudah sangat diperlukan ketika individu memasuki usia remaja menuju dewasa. Usia remaja menuju dewasa dalam tahapan perkembangan karir adalah usia dimana individu berada pada jenjang pendidikan 
perguruan tinggi atau disebut mahasiswa.

Perkembangan karakter kinerja dalam diri individu dipengaruhi oleh 4 faktor yaitu : 1) faktor genetik, 2) faktor keluarga, 3) faktor sosial budaya, serta 4) faktor pendidikan. Trend penelitian bimbingan karir dan karakter kinerja dewasa ini cenderung dilakukan melalui pendekatan pendidikan dan pola asuh. (Russ-Eft, Dickison, \& Levine, 2008) meneliti tentang pengaruh sertifikasi terhadap kesuksesan karir. Penelitian ini dilakukan dengan pendekatan pendidikan. American Institute for Research (2013) meneliti tentang kampus dan kesiapan karir dengan meninjau pengaruh kebijakan kampus, program dan tujuan. (Hameed \& Waheed, 2011) meneliti tentang kinerja karyawan yang diukur melalui aspek tingkat pendidikan, skill, minat dan bakat.

Budaya merupakan salah satu faktor yang mempengaruhi pola pikir individu dalam berperilaku. Namun bimbingan karir dengan pendekatan budaya masih sangat jarang dilakukan. (Kerka, 2003) menyatakan penelitian karir berbasis budaya masih jarang dilakukan, padahal keragaman budaya adalah fakta kehidupan di Amerika Serikat. Praktisi pengembangan karir harus siap dengan sensitifitas budaya dan menanganinya dengan cara yang tepat. (Ma'ruf, 2019; Rosida, 2018; Sarumpaet, 2016; Sumarsilah, 2017) menyatakan manusia menciptakan budaya dan sekaligus manusia diciptakan oleh budaya. Hubungan timbal balik ini menyebabkan

munculnya pandangan tentang manusia hidup dalam perspektif budaya. Karena manusia hidup dalam perspektif budaya, maka aspek budaya merupakan salah satu pendekatan yang tepat untuk digunakan dalam usaha mempengaruhi perspektif individu tentang sesuatu hal termasuk mempengaruhi karakter kinerja.

Bimbingan karir merupakan salah satu bidang layanan dalam ilmu dan praksis bimbingan dan konseling yang memberikan fokus layanan terkait masalah vokasional. Masalah karir menjadi sesuatu yang sangat penting dikembangkan sepanjang kehidupan individu, dan menjadi fokus sentral ketika individu sudah beranjak dewasa. Usia beranjak dewasa adalah ketika individu mulai memasuki usia 18-21 tahun atau tahapan transisi dalam teori perkembangan karir Donal Super.

Karir memainkan peranan yang sangat penting bagi individu dalam membangun identitas, gaya hidup dan perasaan menyenangkan untuk banyak orang dewasa. Bekerja menjadi tempat utama bagi individu dewasa untuk mengembangkan penguasaan atas tugas, ilmu pengetahuan dan keahlian yang dimiliki (Andersen \& Vandehey, 2012). Karir menjadi salah satu faktor yang mempengaruhi tingkat kebahagian individu.

(Gladding, 2012) mengemukakan pendapat beberapa ahli tentang faktor yang mempengaruhi perkembangan karir, seperti gaya kepribadian, tahap perkembangan dan peran kehidupan mempengaruhi perkembangan karir individu (Drummond \& Ryan, 1995), 
kebetulan dan takdir (Guindon \& Hanna, 2002), latar belakang keluarga (Chope, Terry, \& White, 2006), jenis kelamin (Ali, McWhirter, \& Chronister, 2005), Bakat (Maxwell, 2007), dan usia. Penjelasan tersebut diatas adalah faktor-faktor umum yang mempengaruhi perkembangan karir individu. Beberapa ahli juga menyatakan ada faktor-faktor tambahan yang mempengaruhi perkembangan karir seseorang, seperti ekonomi global (Borgen, Senie, McKinnon, \& Rosen, 1997), kecermatan, kepatuhan dan performa kerja adalah keahlian yang dibutuhkan untuk sukses. Kerjasama tim yang kompetitif, kepuasan pelanggan, pembelajaran yang berkelanjutan dan innovasi adalah faktor penting untuk kesuksesan karir (Staley \& Carey, 1997).

Karakter Kinerja menjadi perhatian yang sangat utama dalam era globalisasi dan dalam menyambut dekade abad 21. Perkembangan teknologi informasi menimbulkan persaingan yang sangat ketat dan perjuangan yang lebih berat dalam menguasai dunia kerja dan meraih kesuksesan karir. Karakter Kinerja menjadi fokus perhatian dalam bimbingan dan konseling karir dan menjadi fokus penelitian dalam dunia pendidikan.

Tindak lanjut dari penelitian ini mengarah kepada disusunnya sebuah Strategi Bimbingan Karir Berbasis Merantau Etnik Minangkabau untuk Mengembangkan Karakter Kinerja Mahasiswa. Mengungkapkan profil karakter kinerja mahasiswa merupakan bagian penting dalam penyusunan strategi tersebut.

\section{METODE PENELITIAN}

Metode penelitian ini menggunakan metode kuantitatif deskriptif. Analisis deskriptif digunakan untuk membantu merangkum trend atau kecenderungan secara keseluruhan data yang diperoleh. Metode deskriptif adalah suatu metode yang digunakan untuk menggambarkan atau menganalisis suatu hasil penelitian tetapi tidak digunakan untuk membuat kesimpulan yang lebih luas. Penelitian dilakukan terhadap 95 orang mahasiswa etnik Minangkabau pada semester 5 di perguruan tinggi swasta. Menggunakan mahasiswa semester 5 dengan pertimbangan mahasiswa semester 5 telah memiliki pemahaman yang cukup tentang hakikat karakter kinerja dan sudah memahami pentingnya mengembangkan karakter kinerja untuk diri sendiri dan menghidupkannya dalam suasana akademis di kampus.

Alat ungkap yang digunakan adalah instrumen karakter kinerja mahasiswa yang sudah melalui proses uji coba yang lengkap antara lain expert judgement oleh 3 orang ahli. Kemudian telah dilakukan uji validitas dan reliabilitas. Selain itu telah dilakukan uji keterbacaan melalui wawancara kepada 10 orang mahasiswa. Semua proses uji coba tersebut menyatakan bahwa instrumen 
karakter kinerja mahasiswa layak digunakan dalam proses penelitian.

Untuk mengolah data instrumen, peneliti menggunakan cara manual dengan mencari persentasi nilai dari setiap item, dari setiap aspek dan ratarata keseluruhan karakter kinerja mahasiswa. Dalam menginterpretasi data yang diperoleh dari skala Guttman, Meskipun alternatif jawaban terdiri dari 5 alternatif, namun interpretasi nilai dibagi menjadi tiga bagian seperti berikut ini.

Interpretasi data yang diperoleh dari skala Likert, meskipun alternatif jawaban terdiri dari 5 alternatif, namun interpretasi nilai dibagi menjadi tiga bagian yang diolah dengan menggunakan rumus yang dikemukakan oleh (Farida, 2015; Sudjana, 1996), sebagai berikut:

1). Menentukan rentang skor

$$
\begin{aligned}
& R=x_{t}-x_{r} \\
& \text { Di mana: } \\
& R=\text { rentang } \\
& x_{t}=\text { data terbesar dalam kelompok } \\
& x_{r}=\text { data terkecil dalam kelompok }
\end{aligned}
$$

2). Menentukan panjang kelas interval

$$
\mathrm{P}=\frac{R}{K}
$$

Di mana:

$\mathrm{P} \quad=$ panjang kelas interval

$\mathrm{R}$ = rentang

$\mathrm{K}$ = panjang kelas

Dari hasil pengolahan data maka kategori skor ditentukan dengan kriteria sebagaimana tabel diuraikan dalam tabel 2 berikut ini.

\section{Tabel 2}

Kategori Skor Karakter Kinerja Mahasiswa

\begin{tabular}{cc}
\hline Kategori & Rentang Skor \\
\hline Berkualitas & $X>52 \%$ \\
Cukup Berkualitas & $36 \%-51,9 \%$ \\
Kurang Berkualitas & $0 \%-35,9 \%$ \\
\hline
\end{tabular}

Kategori skor tersebut digunakan untuk memudahkan proses penilaian dan membantu dalam proses analisis data yang telah ditemukan.

\section{HASIL PENELITIAN DAN PEMBAHASAN}

Karakter kinerja mahasiswa etnik Minangkabau diungkap dengan inventori karakter kinerja yang sudah teruji baik keterbacaan, pandangan ahli, validitas dan reliabilitasnya. Inventori karakter kinerja disebarkan kepada 95 orang mahasiswa STKIP Adzkia. Aspek yang diungkap meliputi : 1) aspek pengetahuan dengan indikator kritis, argumentatif dan antisipatif. 2) aspek sikap dengan indikator penghayatan diri, rasa sosial dan keyakinan diri, 3) aspek keterampilan dengan indikator bertutur komunikatif, kerjasama tim dan pengentasan masalah. Presentasi hasil meliputi profil karakter kinerja mahasiswa secara keseluruhan dan hasil profil karakter kinerja mahasiswa per aspek yang diteliti.

\section{Hasil Pengolahan Data Profil Karakter Kinerja Mahasiswa Etnik Minangkabau}

Hasil penelitian menunjukkan bahwa karakter kinerja mahasiswa etnik Minangkabau 66,32\% berada pada kategori berkualitas, 33,68\% 
berada pada kategori cukup berkualitas, dan $0 \%$ berada pada kategori kurang. Tabel 3 berikut menyajikan secara lengkap profil karakter kinerja mahasiswa etnik Minangkabau.

Tabel 3

Profil karakter kinerja mahasiswa Etnik Minangkabau

\begin{tabular}{lcc}
\hline Kriteria & Frekuensi & Persentase \\
\hline Berkualitas & 63 & 66.32 \\
\hline $\begin{array}{l}\text { Cukup } \\
\text { Berkualitas }\end{array}$ & 32 & 33.68 \\
\hline $\begin{array}{l}\text { Kurang } \\
\text { Berkualitas }\end{array}$ & 0 & 0.00 \\
\hline Jumlah & 95 & 100 \\
\hline
\end{tabular}

Bila digambarkan dalam bentuk grafik, maka tersaji seperti pada Grafik 2 berikut.

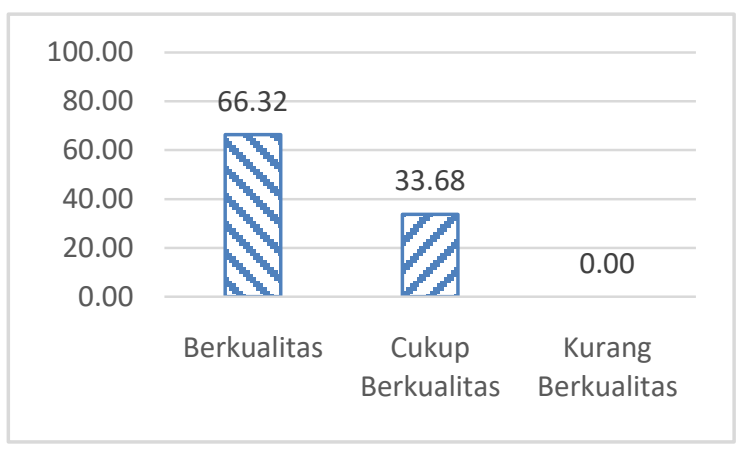

Grafik 2

Profil Karakter Kinerja Mahasiswa Etnik Minangkabau

\section{b. Profil Aspek Pengetahuan Karakter Kinerja Mahasiswa Etnik Minangkabau}

Hasil penelitian menunjukkan bahwa aspek pengetahuan karakter kinerja mahasiswa etnik Minangkabau 54,74\% berada pada kategori berkualitas, 45,26\% berada pada kategori cukup berkualitas, dan $0 \%$ berada pada kategori kurang berkualitas. Grafik 3 menggambarkan perkembangan karakter kinerja mahasiswa pada aspek pengetahuan.

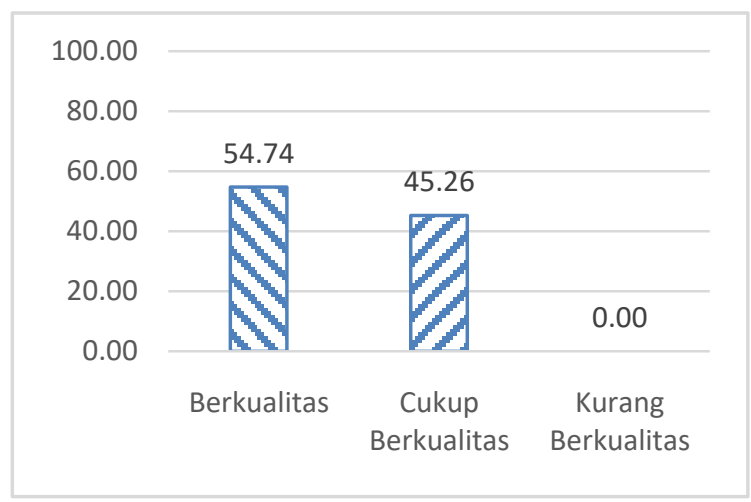

Grafik 3

Profil Aspek Pengetahuan Karakter Kinerja Mahasiswa Etnik Minangkabau

Jika profil aspek pengetahuan karakter kinerja mahasiswa etnik Minangkabau tersebut diuraikan berdasarkan indikator-indikatornya, maka tersaji seperti pada Grafik 4 berikut.

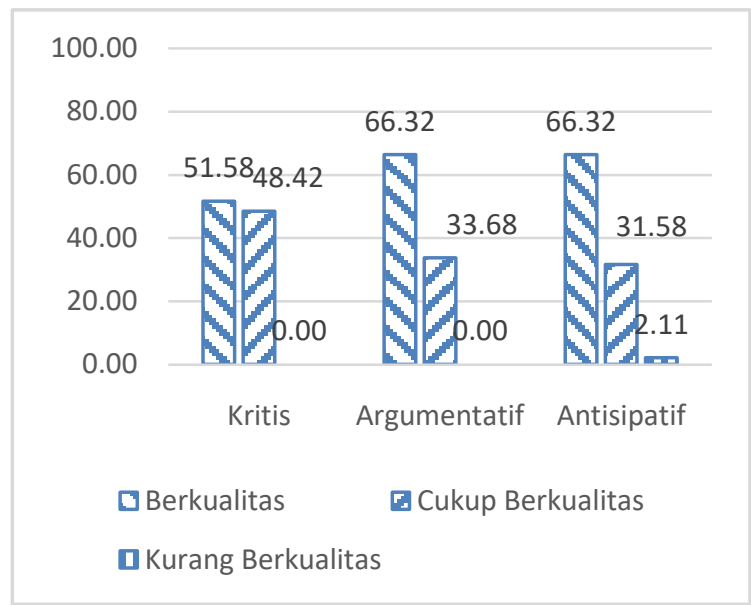

\section{Grafik 4}

Profil Indikator Aspek Pengetahuan Karakter Kinerja Mahasiswa Etnik Minangkabau 


\section{a. Profil Aspek Sikap karakter kinerja mahasiswa Etnik Minangkabau}

Hasil penelitian menunjukkan bahwa aspek sikap karakter kinerja mahasiswa etnik Minangkabau 74,74\% berada pada kategori berkualitas, $25,26 \%$ berada pada kategori cukup berkualitas, dan $0 \%$ berada pada kategori kurang berkualitas. Bila digambarkan dalam bentuk grafik, maka tersaji seperti pada Grafik berikut.

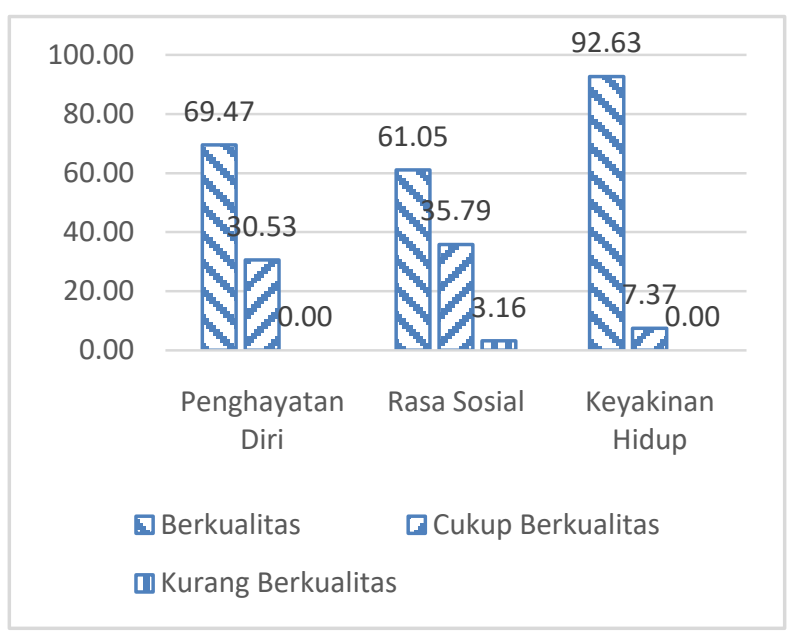

Grafik 5

Profil Indikator Aspek Sikap Karakter

Kinerja Mahasiswa Etnik Minangkabau

\section{b. Profil Aspek Keterampilan karakter kinerja mahasiswa Etnik Minangkabau}

Hasil penelitian menunjukkan bahwa aspek keterampilan karakter kinerja mahasiswa etnik Minangkabau $47,37 \%$ berada pada kategori berkualitas, $52,63 \%$ berada pada kategori cukup berkualitas, $0 \%$ berada pada kategori kurang berkualitas dan $0 \%$ berada pada kategori tidak berkualitas. Bila digambarkan dalam bentuk grafik, maka tersaji seperti pada Grafik 6 berikut.

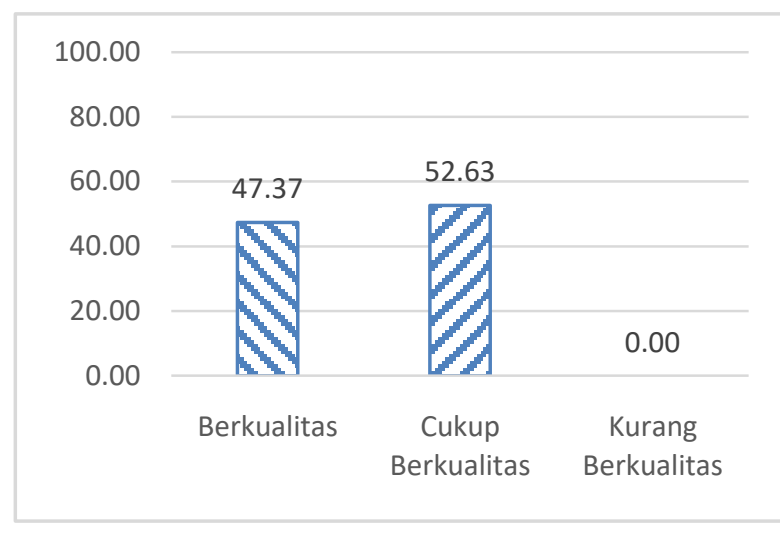

\section{Grafik 6}

Profil Aspek Keterampilan Karakter Kinerja Mahasiswa Etnik Minangkabau

Jika profil aspek keterampilan karakter kinerja mahasiswa etnik Minangkabau tersebut diuraikan berdasarkan indikator-indikatornya, maka tersaji pada tabel berikut.

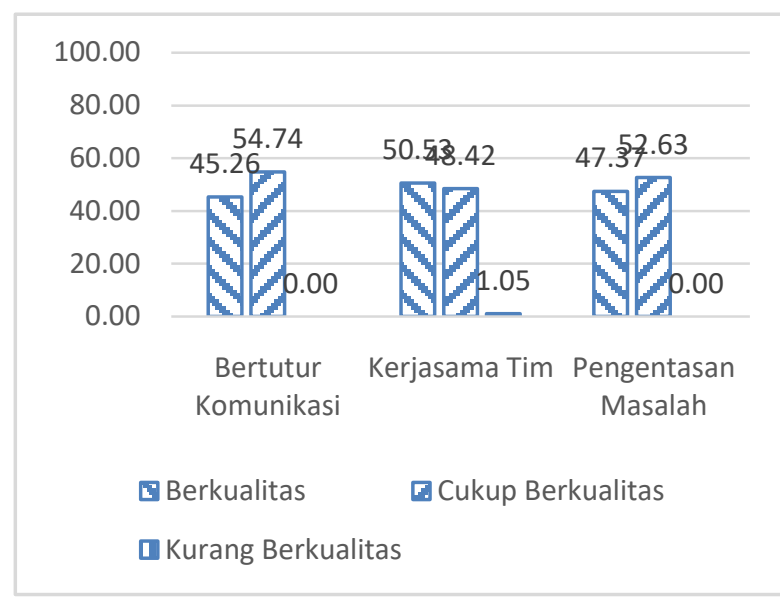

\section{Grafik 7}

Profil Indikator Aspek Keterampilan

Karakter Kinerja Mahasiswa Etnik Minangkabau

Karakter kinerja sangat diperlukan dalam menyambut era 4.0 (four point zero era). Arus globalisasi pada era industri 4.0 menuntut peningkatan kompetensi keterampilan internasional (International skills competences). Pemahaman tradisional tentang kompetensi internasional menyatakan bahwa hal penting yang 
diperlukan agar mampu bersaing di pasar tenaga kerja global adalah kemampuan bahasa, toleransi dan pengetahuan budaya. Namun pemahaman kontenporer tentang kompetensi internasional adalah produktivitas, rasa ingin tahu dan ketangguhan (Nihlah, Faishol, \& Hum, 2017).

\section{Produktivitas}

(productivity)

meliputi efisiensi, kemampuan analitik, kemampuan memecahkan masalah dan kredibilitas. Ketangguhan (resilience) karyawan meliputi kemampuan adaptasi, mengetahui kelemahan dan kekuatan diri, percaya diri dan gigih. Rasa ingin tahu (curiosity) terkait pengalaman internasional meliputi semangat belajar, tertarik pada berbagai isu baru, pengetahuan tentang berbagai budaya, dan kemampuan jaringan. Faktor ini membantu kita untuk memahami nilai dari kompetensi internasional.

Pengembangan karakter kinerja sangat diperlukan ketika individu sudah memasuki pendidikan di perguruan tinggi. Pentingnya mengembangkan karakter kinerja di perguruan tinggi diperkuat oleh Peraturan Pemerintah Nomor 17 tahun 2010 tentang Pengelolaan dan Penyelenggaraan Pendidikan pasal 84 ayat 2 menyatakan bahwa perguruan tinggi memiliki tujuan membentuk insan yang beriman dan bertaqwa kepada Tuhan Yang Maha Esa, berakhlak mulia, dan berkepribadian luhur, sehat, berilmu dan cakap, kritis, kreatif, inovatif, mandiri, percaya diri, dan berjiwa wirausaha, serta toleran, peka sosial dan lingkungan, demokratis dan bertanggung jawab.

Semua karakter kinerja baik berdasarkan pandangan kontemporer dari era 4.0 dan peraturan pemerintah
No. 17 tahun 210 tentang tujuan pendidikan di perguruan tinggi menunjukkan pentingnya karakter kinerja dikembangkan dalam diri mahasiswa. Hasil penelitian menunjukkan indikator karakter kinerja mahasiswa etnik tnik Minangkabau berdasarkan rangking kualitas karakter kinerja dapat dilihat pada tabel berikut ini.

\section{Tabel 4}

\section{Rangking Kualitas Karakter Kinerja} Mahasiswa Etnik Minangkabau

\begin{tabular}{|c|c|c|c|}
\hline Indikator & Aspek & $\begin{array}{l}\text { Persen } \\
\text { tase }\end{array}$ & $\begin{array}{l}\text { Frek/r } \\
\text { esp }\end{array}$ \\
\hline $\begin{array}{l}\text { Keyakinan } \\
\text { Diri (sikap } \\
\text { religius) }\end{array}$ & Sikap & 92,63 & $\begin{array}{l}88 / 95 \\
\text { orang }\end{array}$ \\
\hline $\begin{array}{l}\text { Penghayatan } \\
\text { diri }\end{array}$ & Sikap & 69,47 & $\begin{array}{l}66 / 95 \\
\text { orang }\end{array}$ \\
\hline Argumentatif & $\begin{array}{l}\text { Penge- } \\
\text { tahuan }\end{array}$ & 66,32 & $\begin{array}{l}63 / 95 \\
\text { orang }\end{array}$ \\
\hline Antisipatif & $\begin{array}{l}\text { Penge- } \\
\text { tahuan }\end{array}$ & 66,32 & $\begin{array}{l}63 / 95 \\
\text { orang }\end{array}$ \\
\hline Rasa Sosial & Sikap & 61,05 & $\begin{array}{l}58 / 95 \\
\text { orang }\end{array}$ \\
\hline Kritis & $\begin{array}{l}\text { Penge- } \\
\text { tahuan }\end{array}$ & 51,58 & $\begin{array}{l}49 / 95 \\
\text { orang }\end{array}$ \\
\hline $\begin{array}{l}\text { Kerjasama } \\
\text { Tim }\end{array}$ & $\begin{array}{l}\text { Keteram } \\
\text { pilan }\end{array}$ & 50,53 & $\begin{array}{l}48 / 95 \\
\text { orang }\end{array}$ \\
\hline $\begin{array}{l}\text { Pengentasan } \\
\text { Masalah }\end{array}$ & $\begin{array}{l}\text { Keteram } \\
\text { pilan }\end{array}$ & 47,37 & $\begin{array}{l}45 / 95 \\
\text { orang }\end{array}$ \\
\hline $\begin{array}{l}\text { Bertutur } \\
\text { Komunikatif }\end{array}$ & $\begin{array}{l}\text { Keteram } \\
\text { pilan }\end{array}$ & 45,26 & $\begin{array}{l}43 / 95 \\
\text { orang }\end{array}$ \\
\hline
\end{tabular}

Allah tuhan YME mendapatkan ranking tertinggi dalam pengolahan data profil karakter kinerja mahasiswa. Profil keyakinan diri (religiusitas) mahasiswa sejalan dengan budaya etnik Minangkabau yang dikenal sebagai masyarakat yang religius. Hal ini terungkap dari beberapa pandangan tokoh seperti ungkapan (Arif, 2011), "kunci kekuatan bisnis orang Padang terletak pada adatnya yang bersendikan syarak, syarak yang 
bersendikan kitabullah". (Sanggoeno, 2009), menyatakan lima perkara batin orang Minang yaitu : (1) berkata-kata untuk kebajikan, (2) berbuat ibadat, (3) senantiasa takut kepada Allah SWT, (4) mengaku besar dosa dirinya dan 5) menahan diri terhadap sesuatu yang tidak bermanfaat. (Yulika \& Hum, 2017) menyatakan filosofi Minang "adat basandi syarak, syarak basandi kitabullah" merupakan penyatuan dua hal yang bersifat universal (syarak) dan spesifik (adat). Keduanya tidak bertentangan karena prinsip yang dipakai adalah persamaan, alur dan patut (norma\& kepantasan) dan keduanya tidak saling bertentangan.

Religiusitas etnik Minangkabau dikuatkan oleh berbagai hasil penelitian. (Welsa, Suharti, \& Latifah, 2018) menyatakan bahwa keberadaan Restoran Padang didukung oleh kekuatan norma-norma yang berasal dari sosial dan budaya Minang berdasarkan ajaran Islam (adat didasarkan pada Islam, Islam didasarkan pada Kitab Suci Al-Quran). Hasil penelitian (Welsa et al., 2018), indikator agama mendapat nilai tertinggi pada pertanyaan jenis makanan yang diproduksi adalah makanan yang dijamin halal sebesar 4,62 . Hal tersebut sudah sesuai dengan falsafah budaya minang kabau berasaskan falsafah budaya Minangkabau yaitu adat bersandikan syarak, syarak bersandikan kitabullah, yaitu berdasarkan aturan-aturan agama Islam. Apabila masyarakat yang beragama islam bepergian ke luar negeri akan selalu mencari rumah makan padang karena yakin akan kehalalannya walau tanpa mendapatkan sertifikat halal dari MUI. Hasil penelitian (Santoso \& Safitri, 2019; A Ashary (2016) mengungkap bahwa religiusitas dan cultural belief memiliki pengaruh secara umum dalam perilaku produksi dan konsumsi Muslim Minangkabau di Sumatera Barat. Namun setelah dilihat per lokasi diperoleh hasil yang beragam; ada yang berpengaruh signifikan dan ada yang tidak.

Indikator penghayatan diri merupakan indikator dari aspek sikap menempati urutan kedua sebesar $69.47 \%$ pada kriteria berkualitas. Keyakinan diri dalam istilah lain disebut konsep diri (self concept) atau keyakinan pada diri (self confidence), self efficacy, self esteem dan beberapa istilah lainnya. (Calhoun \& Acocella, 1990) menjelaskan bahwa konsep diri terdiri atas tiga dimensi yang meliputi : (1) pengetahuan terhadap diri sendiri (real-self), (2) pengharapan mengenai diri sendiri (ideal-self), (3) penilaian sosial tentang diri (social-self).

Pengenalan, pengharapan dan penilaian terhadap diri sendiri mempengaruhi individu dalam bereaksi terhadap lingkungan. Kepercayaan diri yang rendah akan menyebabkan individu menarik diri dari lingkungan, sebaliknya individu dengan kepercayaan diri yang tinggi berani keluar dari zona aman dan mengeksplorasi lingkungan untuk pengembangan dirinya. Individu dengan kepercayaan diri yang tinggi memiliki keberanian mengambil keputusan, gigih, percaya diri dan selalu menginginkan standar maksimal pada pencapaian tujuan. Budaya 
merantau etnik Minangkabau banyak mengajarkan nilai-nilai penghayatan diri dan merantau sendiri menjadi ajang latihan terhadap indikator penghayatan diri.

Indikator argumentatif dan antisipatif mendapat persentase angka yang sama dalam perhitungan statistik karakter kinerja mahasiswa (66,32\%) dengan kriteria berkualitas. Indikator argumentatif dan antisipatif merupakan aspek pengetahuan dalam kajian karakter kinerja. Dari hasil pengolahan data terlihat 4 karakter kinerja mahasiswa yang menunjukkan gejala memprihatinkan. Aspek keterampilan dengan indikator bertutur komunikatif, kerjasama tim dan pengentasan masalah berada pada urutan terbawah dengan rata-rata dibawah 50\%. (Trilling, 2009) memasukkan ketiga unsur tersebut sebagai karakter kinerja yang diperlukan agar mampu bersaing di abad 21. Amirudin, (2017) menyatakan individu harus memiliki kemampuan dukungan fungsional dasar seperti membaca, menulis, menghitung, membuat formula dan mengatasi masalah, mengelola sumber daya, bekerja dalam tim dan bekerja menggunakan teknologi untuk dapat melaksanakan tugas dengan baik.

Indikator lain yang cukup memprihatinkan adalah masih ada karakter kinerja mahasiswa dengan kriteria "kurang berkualitas". Dari 95 orang mahasiswa yang diteliti, masih ada 2 orang mahasiswa (2,11\%) yang kurang berkualitas pada indikator karakter kinerja antisipatif, 3 orang mahasiswa $(3,16 \%)$ yang kurang berkualitas dalam indikator karakter kinerja rasa sosial. Indikator antisipatif merupakan indikator yang sangat penting bagi mahasiswa mencapai kesuksesan akademik apalagi kesuksesan karir. Karakter kinerja antisipatif membantu mahasiswa mempercepat penyelesaian tugas-tugas belajar. Karakter kinerja antisipatif menjadikan mahasiswa kreatif mencari berbagai alternatif dalam menyelesaikan masalah.

Karakter kinerja rasa sosial merupakan indikator yang paling penting bagi etnik Minangkabau sebagai perantau dalam kehidupan. Rasa sosial membantu perantau dalam mendapatkan kenyamanan hidup, bantuan sosial dan percepatan pencapaian tujuan yang akan berpengaruh kepada kesuksesan karir. Lima orang mahasiswa yang masih rendah kualitas karakter kinerja antisipatif dan rasa sosial perlu mendapatkan bimbingan individual untuk menemukan kendala pribadi dalam dua karakter kinerja tersebut.

Pembahasan diatas memberikan kesimpulan, karakter kinerja mahasiswa etnik Minangkabau berkualitas pada indikator keyakinan diri, penghayatan diri, antisipatif, argumentatif dan rasa sosial. Karakter kinerja mahasiswa etnik Minangkabau cukup berkualitas dalam indikator kritis, bertutur komunikatif, kerjasama tim dan pengentasan masalah. Hasil penelitian ini mendukung hasil penelitian sebelumnya tentang kapasitas dan kepribadian mahasiswa. Hasil penelitian Supriatna (2010) yang menemukan bahwa mahasiswa masih 
kesulitan dalam memahami sifat-sifat diri sendiri $(24,91 \%)$, mahasiswa belum dapat mengungkapkan potensi diri (50,90\%), mahasiswa tidak mengutama-kan pemeliharaan dan pemanfaatan potensi diri $(9,03 \%)$. Evaluasi menyeluruh terhadap tingkat keman-dirian pelajar terutama mahasiswa diperguruan tinggi menunjukkan gejala yang memprihatin-kan. Hasil penelitian (Kartadinata, 1988) menemukan tiga gejala yang meresahkan tentang persoalan kemandirian manusia Indonesia, yaitu : (1) ketergantungan disiplin kepada kontrol luar bukan karena niat sendiri yang ikhlas, (2) sikap tidak peduli terhadap lingkungan hidup (3) sikap hidup konformistik tanpa pemahaman dan kompromistik dengan mengorbankan prinsip.

\section{KESIMPULAN}

Karakter Kinerja adalah hal yang sangat penting dikembangkan dalam diri peserta didik sejak usia dini sampai dewasa. Karakter kinerja pada diri mahasiswa diharapkan sudah terinternalisasi dan menjadi kebiasaan. Karakter kinerja dapat dikembangkan melalui berbagai pendekatan, seperti pendekatan pendidikan, lingkungan, sosial dan pendekatan budaya.

Profil karakter kinerja mahasiswa etnik Minangkabau diungkapkan melalui Studi Nomotetik. Hasil studi menunjukkan fakta tentang karakter kinerja mahasiswa berdasarkan tiga aspek karakter kinerja dan sembilan indikator karakter kinerja yang perlu dikembangkan di perguruan tinggi yaitu indikator kritis, argumentatif, antisipatif, penghayatan diri, rasa sosial, keyakinan diri, bertutur komunikatif, kerjasama tim dan pengentasan masalah. Karakter kinerja mahasiswa etnik Minangkabau perlu dikembang-kan lebih maksimal agar mendapat kemudahan dalam mencapai kesuksesan karir setelah lulus dari perguruan tinggi.

\section{REFERENSI}

Ali, S. R., McWhirter, E. H., \& Chronister, K. M. (2005). Selfefficacy and vocational outcome expectations for adolescents of lower socioeconomic status: A pilot study. Journal of Career Assessment, 13(1), 40-58.

Airas \& Tuominen, (2014). The Extended Understanding of International Experience. Euro Gudance. Erasmus+. Leaflet "open the Door to the World, Views on Mobility Guidance from UP North"

Andersen, P., \& Vandehey, M. (2012). Career counselling and development. A Global Economy.

Anggraini, S. (2017). Bimbingan Karier Dalam Menciptakan Kreativitas Anak Di Smp Yayasan Pendidikan Harapan Tegineneng (YPHT) (PhD Thesis). UIN Raden Intan Lampung. 
Amirudin. (2017). Concept of life skill Education and Implementation in the Study Program Islamic Religious Education Faculty of Islamic Islam UNSIKA. Proceeding Seminar and Workshop Educational Psychology; Career Development in Psychology and Educational Perspective. ISBN. 9786025065200 (hlm.43-53).

Arif, M. (2011). Entrepreneurship Dalam Perspektif Ekonomi Islam (Studi Kasus Terhadap Pengusaha Rumah Makan dan Restoran Etnis Minang "Sederhana"(SA) Jl. A. Yani Pekanbaru) (PhD Thesis). Universitas Islam Negeri Sultan Syarif Kasim Riau.

Astawa, I. M. O. (2016). Kinerja Konselor Dalam Mempersiapkan Generasi Emas Pada Masyarakat Multi Kultural Dan Modern. Jurnal Penjaminan Mutu, 2(2), 109-126.

Astuti, A. J. (2017). Pengaruh Kompetensi dan Pengembangan Karir Terhadap Kinerja Karyawan Studi Pada PT Harda Esa Raksa (PhD Thesis). Universitas Widyatama.

Atikah, U. (2016). Implementasi bimbingan dan konseling di SD Islam Al-Azhar 29 BSB Semarang tahun pelajaran 2015/2016 (PhD Thesis). UIN Walisongo.

Badan Pusat Statistik Republik Indonesia.

www.bps.go.id/diakses tanggal 13Februari 2019
Ballout, H. I. (2007). Career success: The effects of human capital, person-environment fit and organizational support. Journal of Managerial Psychology, 22(8), 741-765.

Bartin, T. (2018). Pendidikan orang dewasa sebagai basis pendidikan non formal. Jurnal Teknodik, 10(19), 156-173.

Borgen, P. I., Senie, R. T., McKinnon, W. M., \& Rosen, P. P. (1997). Carcinoma of the male breast: Analysis of prognosis compared with matched female patients. Annals of Surgical Oncology, 4(5), 385-388.

Calhoun, J. F., \& Acocella, J. R. (1990). Psikologi tentang penyesuaian dan hubungan kemanusiaan (edisi ketiga). Satmoko, RS (Penerjemah) New York: McGraw-Hill.

Chope, G. A., Terry, L. A., \& White, P. J. (2006). Effect of controlled atmosphere storage on abscisic acid concentration and other biochemical attributes of onion bulbs. Postharvest Biology and Technology, 39(3), 233-242.

Drummond, R. J., \& Ryan, C. W. (1995). Career Counseling: A Developmental Approach. ERIC.

Faqeer-Ul-Ummi, U. Y., Javed, R., \& Amjad, M. (2014). Impact of personality on career success. International Journal of Innovation and Applied Studies, 9(3), 1064. 
Farida, F. (2015). Mengembangkan kemampuan pemahaman konsep peserta didik melalui pembelajaran berbasis VCD. Al-Jabar: Jurnal Pendidikan Matematika, 6(1), 25-32.

Gladding, S. T. (2012). Konseling: Profesi yang Menyeluruh.(alih bahasa: PM Winarno), Edisi Keenam, Jakarta: PT. Indeks.

Guindon, M. H., \& Hanna, F. J. (2002). Coincidence, happenstance, serendipity, fate, or the hand of God: Case studies in synchronicity. The Career Development Quarterly, 50(3), 195-208.

Hameed, A., \& Waheed, A. (2011). Employee development and its affect on employee performance a conceptual framework. International Journal of Business and Social Science, 2(13).

Haryani, C., Wadin, W., \& Sofino, S. (2014). Penerapan metode bermain dengan media playdough dalam meningkatkan kemampuan mengenal konsep bilangan dan lambang bilangan pada anak usia dini (PhD Thesis). Universitas Bengkulu.

Husin, M. (2018). Pengaruh program tarbiyatul amaliyah terhadap pembentukan karakter keguruan siswa kelas XI di MAN Genukwatu Ngoro Jombang (PhD Thesis). UIN Sunan Ampel Surabaya.
Indana, N. (2017). Implementasi Total Quality Management (TQM) dalam Meningkatkan Mutu Pendidikan. Al-Idaroh: Jurnal Studi Manajemen Pendidikan Islam, 1(1), 62-86.

Kartadinata, S. (1988). Profil kemandirian dan orientasi timbangan sosial mahasiswa serta kaitannya dengan perilaku empatik dan orientasi nilai rujukan: Studi deskriptif analitik tentang kemandirian mahasiswa pada beberapa perguruan tinggi negeri dan swasta di Kotamadya Bandung. Fakultas Pasca Sarjana, Institut Keguruan dan Ilmu Pendidikan.

Kartika, E. W., \& Kaihatu, T. S. (2010). Analisis pengaruh Motivasi kerja terhadap kepuasan kerja (studi kasus pada karyawan restoran di Pakuwon Food Festival Surabaya). Jurnal Manajemen Dan Kewirausahaan, 12(1), 100-112.

Kerka, S. (2003). Career development of diverse populations. ERIC Clearinghouse.

Mahadin Shaleh, M. S., \& Firman, S. P. (2018). Komitmen Organisasi Terhadap Kinerja Pegawai. Penerbit Aksara Timur.

Ma'ruf, M. (2019). Konsepsi Emha Ainun Nadjib tentang Relasi Islam dan Budaya dalam Perspektif Filsafat Budaya (PhD Thesis). UIN Sunan Ampel Surabaya. 
Maxwell, J. C. (2007). The 21 irrefutable laws of leadership: Follow them and people will follow you. HarperCollins Leadership.

Meithiana, I. (2017). Kepuasan Kerja dan Kinerja Karyawan Tinjauan dari Dimensi Iklim Organisasi, Kreativitas Individu, dan Karakteristik Pekerjaan. Indomedia Pustaka.

Muhammad, H., Dasar, D. J. P., Oleh, M. D., \& Supriano, M. (2017). Peran Guru Bimbingan dan Konseling atau Konselor dalam Penguatan Karakter dan Pengembangan Karier Peserta Didik. Seminar Bimbingan Dan Konseling Universitas Negeri Malang. Malang: Universitas Negeri Malang.

Nihlah, A. M., Faishol, A., \& Hum, M. (2017). Pendidikan Karakter Perspektif Religius dan Nasionalis Dalam Novel Kupilih Jalan Gerilya Roman Hidup Panglima Besar Jenderal Soedirman Karya E. Rokajat Asura (PhD Thesis). IAIN Surakarta.

Putra, H. F., \& Suharnomo, S. (2012). Analisis Pengaruh Kepemimpinan, Motivasi dan Lingkungan Kerja terhadap Kinerja Pegawai Badan Diklat Provinsi Jawa Tengah (PhD Thesis). Fakultas Ekonomika dan Bisnis.
Rosida, I. (2018). Tubuh Perempuan dalam Budaya Konsumen: Antara Kesenangan Diri, Status Sosial, dan Nilai Patriarki. Jurnal Antropologi: Isu-Isu Sosial Budaya, 20(1), 85-101.

Russ-Eft, D., Dickison, P., \& Levine, R. (2008). Certification and Career Success: A LEADS Project. Online Submission.

Sanggoeno, D. I. (2009). Tambo Alam Minangkabau. Bukitttinggi: Kristal Multimedia.

Santoso, S., \& Safitri, A. (2019). Kesadaran Esensial Motivasi Belajar Agama Islam pada Kaum Mualaf Suku Akit Desa Penyengat Kecamatan Sungai Apit Kabupaten Siak. ANNAFS, 13(01), 1-20.

Sarumpaet, R. K. T. (2016). Krisis Budaya?: Oasis Guru besar Fakultas Ilmu Budaya UI. Yayasan Pustaka Obor Indonesia.

Staley, W. L., \& Carey, A. L. (1997). The role of school counselors in facilitating a quality twentyfirst century workforce. The School Counselor, 44(5), 377-383.

Sudjana, N. (1996). Teknik analisis regresi dan korelasi. Bandung: Tarsito.

Suherman, U. (2009). Konseling karir sepanjang rentang kehidupan. Bandung: Sekolah Pascasarjana UPI Bandung. 
Sumarsilah, S. (2017). Mengkaji NilaiNilai Moral dalam Puisi sebagai Media Pendidikan Moral. Paradigma: Jurnal Filsafat, Sains, Teknologi, Dan Sosial Budaya, 23(1), 57-56.

Tenriawaru, E. P. (2014). Implementasi mind mapping dalam kegiatan pembelajaran dan pengaruhnya terhadap pendidikan karakter. Prosiding, 1(1), 86-91.

Trilling, B. (2009). Dan Fadel. C."21st Century Skills Learning for Life in Our Times", USA, HB Printing, 45.

Ubaedy, A. N. (2013). Berkarier di Era Global. Elex

Media
Welsa, H., Suharti, S., \& Latifah, L. (2018). Budaya Minangkabau Dan Implementasi Pada Manajemen Rumah Makan Padang di Yogyakarta. Ekuitas (Jurnal Ekonomi Dan Keuangan), 1(2), 181-203.

Yudistira, C. (2014). Implementasi Pendidikan Karakter Peduli Lingkungan di Sekolah Alam Ungaran Kabupaten Semarang (PhD Thesis). Universitas Negeri Semarang.

Yulika, D. F., \& Hum, M. (2017). Epistemologi Minangkabau: Makna Pengetahuan dalam Filsafat Adat Minangkabau. ISI Padang Panjang.

Komputindo. 